\title{
Pertumbuhan Tanaman Stroberi Pada Berbagai Jenis dan Konsentrasi Pupuk Organik Cair dan Urine Sapi Dengan Sistem Hidroponik Irigasi Tetes
}

\author{
NURLAILAH MAPPANGANRO \\ Jurusan Biologi, Fakultas Sains dan Teknologi, UIN Alauddin Makassar \\ Jl. Sultan Alauddin 36 Samata, Kab. Gowa 92113 \\ email: ilha_k@yahoo.co.id
}

\begin{abstract}
The research aimed at investigating the effect of the liquid organic fertilizer from the cattle dung towards the growth of the strawberry plant, the effect of the cow urine fermented on the growth of the strawberry plant, and the effect of the liquid organic fertilizer from the cattle dung and cow urine fermented towards the growth of the strawberry plant. The research was designed by using complete randomized design with three replications with 36 treatments of the types and concentrations of the liquid organic fertilizer and cow urine. The result of the research indicates that the cow liquid organic fertilizer gives the best results on the plant height and the number of leaves of the strawberry plant, whereas the rabbit liquid organic fertilizer gives the best results on the number of flower on every strawberry plant. The addition of the cow urine $\left(50 \mathrm{~mL} \mathrm{~L}^{-1}\right)$ gives the best result on the growth of the strawberry plant. The cow liquid organic fertilizer $\left(6 \mathrm{~mL} \mathrm{~L}^{-1}\right)$ and the cow urine $\left(50 \mathrm{~mL} \mathrm{~L}^{-1}\right)$ give the best results on the plant height and number of leaves, whereas the rabbit liquid organic fertilizer $\left(6 \mathrm{~mL} \mathrm{~L}^{-1}\right)$ and the cow urine $\left(50 \mathrm{~mL} \mathrm{~L}^{-1}\right)$ give the best results on the number of flower of every strawberry plant.
\end{abstract}

Keywords: cattle dun, cow urine, growth of strawbery, liquid organic biofertilizer

\section{PENDAHULUAN}

Stroberi (Fragaria sp.) merupakan salah satu komoditas buah-buahan yang penting di dunia, terutama untuk negara-negara beriklim subtropis. Seiring perkembangan ilmu dan teknologi pertanian yang semakin maju, stroberi kini mendapat perhatian pengembangannya di daerah beriklim tropis. Di Indonesia, walaupun stroberi bukan merupakan tanaman asli Indonesia, namun pengembangan komoditas ini yang berpola agribisnis dan agroindustri dapat dikategorikan sebagai salah satu sumber pendapatan dalam sektor pertanian. Stroberi ternyata dapat tumbuh dan berproduksi dengan baik dalam kondisi iklim seperti di Indonesia.

Tingkat pertumbuhan petani stroberi terus meningkat dari tahun ke tahun Budidaya stroberi telah dicoba oleh beberapa petani di daerah Sukabumi, Cianjur, Cipanas, dan Lembang (Jawa Barat); Batu (Malang); Bedugul (Bali); serta di Loka dan Malino (Sulawesi Selatan). Menurut Badan Pusat Statistik (2011), produksi stroberi Indonesia tahun 2009 sebesar 19.132 ton dan mengalami perkembangan produksi $29,87 \%$ (5.714 ton) pada tahun 2010, dimana jumlah produksi tahun 2010 sebanyak 24.846 ton.

Meskipun perkembangan stroberi di Indonesia terus mengalami peningkatan, namun produktivitas stroberi di daerah-daerah penghasil stroberi masih tergolong rendah jika dibandingkan dengan potensi produktivitas stroberi. Seperti di Desa Tongkoh dan Desa Korpri Sumatera Utara, rerata produktivitas desa Tongkoh per petani adalah 13.847,62 $\mathrm{Kg} / \mathrm{Ha}$ dan Desa Korpri adalah 15.305,67 $\mathrm{Kg} / \mathrm{Ha}$, rerata produktivitas keduanya adalah 14.576,64 Kg/Ha (Aswita, 2007). Untuk memenuhi permintaan pasar yang semakin hari semakin meningkat, beberapa alternatif teknik budidaya dapat dilakukan terhadap tanaman stroberi, dengan harapan, produksi yang dihasilkan optimal, baik kualitas maupun kuantitas. Cara yang dilakukan antara lain dengan sistem penanaman, teknik budidaya yang tepat, dan penggunaan varietas yang mempunyai sifat unggul. 
Nutrisi yang diberikan ke tanaman merupakan hal yang sangat penting dalam sistem hidroponik karena keberhasilan sistem budidaya hidroponik bergantung pada nutrisi yang diberikan. Komposisi, konsentrasi, dan volume larutan nutrisi yang diberikan harus diperhatikan agar sesuai dengan kebutuhan tanaman.

Untuk mengatasi hal tersebut maka kotoran ternak dapat diolah menjadi pupuk organik cair sehingga dapat efisien dalam hal tenaga kerja, biaya, dan konsentrasi yang diberikan sesuai dengan yang dibutuhkan tanaman. Kotoran ternak yang dapat digunakan seperti kotoran sapi, kambing, kelinci, ayam atau ternak lainnya. Penelitian yang telah dilakukan oleh Noor, et al. (1996), memberikan hasil bahwa penggunaan kotoran kelinci pada berbagai sayuran di Sulawesi Selatan menunjukkan peningkatan produksi sebesar 2,1\% (jagung sayur), 11,8\% (kubis), $12,5 \%$ (buncis), 22,7\% (kacang merah) dan $5,5 \%$ (kentang).

Beberapa penelitian mengenai pupuk organik cair telah dilakukan antara lain oleh Parman (2007), dimana penggunaan pupuk organik cair pada konsentrasi $4 \mathrm{ml} / 1$ memberikan hasil yang signifikan terhadap jumlah daun, diameter umbi, berat basah tanaman dan berat basah umbi tanaman kentang. Karena baunya yang khas urine sapi ternak juga dapat mencegah datangnya berbagai hama tanaman sehingga urine sapi juga dapat berfungsi sebagai pengendali hama tanaman. Penelitian terhadap urine sapi juga dilakukan oleh Mardalena (2007), dengan mengunakan konsentrasi urine sapi yang telah difermentasi $25 \mathrm{cc} /$ liter air dan $50 \mathrm{cc} /$ liter air, memberikan hasil bahwa urine sapi berpengaruh nyata terhadap umur berbunga, jumlah bunga betina, umur panen, dan jumlah cabang produktif tanaman mentimun.

\section{METODE}

Pembuatan Pupuk Organik Cair dari Kotoran Ternak. Wadah atau ember plastik disiapkan. Ember diisi dengan air bersih sebanyak 10 liter, lalu dicampurkan dengan MIKROBAT sebanyak $250 \mathrm{ml}$, kemudian ditambahkan dengan molasses sebanyak 250 ml. Setelah itu kotoran ternak sebanyak $10 \mathrm{~kg}$ dimasukkan dan diaduk hingga rata. Kemudian wadah ditutup dengan rapat. Disimpan selama 2 minggu. Pengadukan dilakukan setiap 2 hari sekali. Setelah fermentasi selesai yang ditandai dari adanya bercak-bercak putih, larutan kemudian ditapis. Kemudian larutan pupuk organik cair yang telah jadi disimpan dalam jerigen, dan ditutup rapat. Masing-masing dibuat 4 jenis pupuk organik cair yaitu dari kotoran sapi, kambing, ayam, dan kelinci dengan pelaksanaan yang sama.

Fermentasi Urine Sapi. Urine sapi ditampung sebanyak 10 liter dan dimasukkan ke dalam ember plastik. Lengkuas, kunyit, jahe, dan kencur masing-masing sebanyak 2 ons ditumbuk sampai halus, kemudian dimasukkan ke dalam ember plastik yang berisi urine sapi. Kemudian MIKROBAT dimasukkan sebanyak $250 \mathrm{ml}$, kemudian ditambahkan dengan molasses sebanyak 250 ml. Diaduk hingga rata. Kemudian wadah ditutup dengan rapat. Disimpan selama 2 minggu. Pengadukan dilakukan setiap 2 hari sekali. Setelah fermentasi selesai yang ditandai dari adanya bercak-bercak putih, larutan kemudian ditapis. Kemudian disimpan dalam jerigen, dan ditutup rapat.

Persiapan Media. Media tanam yang digunakan adalah arang sekam. Pertama adalah menyiapkan sekam dalam kondisi kering, kemudian sekam dibakar dengan menggunakan alat khusus untuk membuat arang sekam. Setelah sekam telah terbakar dan berwarna hitam, kemudian disiram dengan air untuk menghentikan pembakaran agar tidak menjadi abu. Arang sekam kemudian dikeringkan. Kemudian polibag diisi dengan arang sekam, polibag yang digunakan ada 2 macam yaitu polibag besar ukuran $50 \times 50$ $\mathrm{cm}$ dan polibag kecil ukuran $20 \times 18 \mathrm{~cm}$. Setelah semua polibag diisi dengan arang sekam, polibag kecil sebanyak 4 buah diletakkan di atas polibag besar. Bagian tepi polibag ditekuk agar posisinya kokoh.

Pemasangan Sistem Irigasi Tetes. Untuk menghemat biaya penggunaan sistem irigasi tetes maka digunakan botol infus. Pertama yaitu menyiapkan bambu yang digunakan 
sebagai tiang tempat botol infus digantung, dengan panjang sekitar $60 \mathrm{~cm}$ dan ditanam disamping polibag. Kemudian botol infus digantung pada bambu dan dibuat lubang pada botol yang dapat ditutup kembali untuk tempat memasukkan larutan nutrisi. Kemudian larutan nutrisi yang nantinya mengalir diteteskan melalui selang dripper (selang infus) yang mempunyai alat yang dapat mengatur besar kecilnya tetesan nutrisi.ke dalam setiap polibag.

Penanaman. Bibit stroberi berasal dari stolon tanaman induk stroberi yang telah berumur 1-2 tahun. Bibit yang digunakan adalah bibit yang pertumbuhannya baik, tegak, segar, bebas dari serangan hama dan penyakit, serta pertumbuhannya seragam, dan telah berumur 2 minggu sejak dibibitkan. Kemudian bibit ditanam ke dalam media tanam dengan terlebih dahulu membuat lubang tanam dengan kedalaman sesuai panjang akar. Kemudian media tanam dipadatkan di sekitar akar.

Penyiraman/ Pemberian Nutrisi. Pemberian nutrisi diintegrasikan dengan penyiraman. Nutrisi berupa pupuk organik cair dilarutkan dengan air, konsentrasi sesuai dengan perlakuan. Air yang digunakan adalah air bersih, tidak mengandung kotoran yang dapat menyumbat selang irigasi. Nutrisi diberikan berupa tetesan-tetesan langsung di sekitar daerah akar tanaman, diberikan secara terus menerus.

Pengaplikasian Urine Sapi. Pengaplikasian urine sapi dilakukan setelah tanaman berumur 1 minggu setelah tanam dan diberikan seminggu sekali. Aplikasi urine sapi diberikan lewat daun dan dilakukan pada pagi hari.

Pemeliharaan. Pemeliharaan tanaman meliputi penyiangan gulma yang dilakukan dengan mencabut gulma yang tumbuh dalam polibag. Pemangkasan dilakukan dengan membuang daun tua dan daun yang terserang hama dan penyakit, karena bisa menularkan penyakit ke tanaman lain. Pengendalian hama dan penyakit dilakukan dengan cara sanitasi, mekanik dan secara fisik, antara lain terhadap kutu daun dengan cara menjaga kebersihan (sanitasi) di dalam Screen House, terhadap serangan ulat tanah dengan cara mengumpulkan dan membunuh ulat, dan dengan menggunakan perangkap botol kuning.

Parameter yang Diukur.

Pertambahan tinggi tanaman $(\mathrm{cm})$, dihitung selisih antara tinggi tanaman pada akhir pengamatan dengan tinggi tanaman pada awal pengamatan. (2) Pertambahan jumlah daun (helai), dihitung selisih antara jumlah daun pada akhir pengamatan dengan jumlah daun pada awal pengamatan (3) Jumlah bunga (bunga), dihitung jumlah bunga yang muncul hingga akhir pengamatan.

\section{HASIL}

Pertambahan tinggi tanaman umur 9 Minggu Setelah Tanam (MST) dan sidik ragam menunjukkan perlakuan berbagai jenis dan konsentrasi pupuk organik cair dengan berbagai konsentrasi urine sapi sangat berpengaruh nyata terhadap pertambahan tinggi tanaman umur 9 MST. Hasil uji kontras ortogonal disajikan pada tabel 1.

Tabel 1. Hasil Uji Kontras Ortogonal Pertambahan Tinggi Tanaman $(\mathrm{cm})$ Stroberi Umur 9 MST

\begin{tabular}{|c|c|c|c|c|c|c|}
\hline No & Perlakuan & \multicolumn{3}{|c|}{ Rata-rata } & \multicolumn{2}{|l|}{$F_{\text {Hitung }}$} \\
\hline 1. & s vs k, a, c & 3,72 & Vs & 3,28 & 254,41 & ** \\
\hline 2. & $\mathrm{kvs} a, \mathrm{c}$ & 2,43 & Vs & 3,47 & 382,68 & ** \\
\hline 3. & a vs c & 3,34 & Vs & 3,59 & 53,94 & ** \\
\hline 4. & $\left(\mathrm{~s}_{1}, \mathrm{~s}_{2}, \mathrm{~s}_{3}\right)$ vs $\left(\mathrm{s}_{4}, \mathrm{~s}_{5}, \mathrm{~s}_{6}\right),\left(\mathrm{s}_{7}, \mathrm{~S}_{8}, \mathrm{~s}_{9}\right)$ & 2,59 & Vs & 4,28 & 1105,26 & ** \\
\hline 5. & $\left(\mathrm{~s}_{4}, \mathrm{~S}_{5}, \mathrm{~S}_{6}\right)$ vs $\left(\mathrm{s}_{7}, \mathrm{~s}_{8}, \mathrm{~s}_{9}\right)$ & 3,71 & Vs & 4,86 & 380,21 & $* *$ \\
\hline 6. & $\mathrm{~S}_{1} \mathrm{VS} \mathrm{S}_{2}, \mathrm{~S}_{3}$ & 1,22 & vs & 3,28 & 547,95 & $* *$ \\
\hline 7. & $\mathrm{~S}_{2} \mathrm{VS} \mathrm{S}_{3}$ & 2,11 & vs & 4,45 & 529,74 & ** \\
\hline 8. & $\mathrm{~S}_{4}$ VS $\mathrm{S}_{5}, \mathrm{~S}_{6}$ & 2,00 & vs & 4,57 & 847,66 & ** \\
\hline 9. & $\mathrm{~S}_{5} \mathrm{VS} \mathrm{S}_{6}$ & 3,15 & vs & 5,98 & 774,03 & ** \\
\hline 10. & $\mathrm{~S}_{7} \mathrm{VS}_{8}, \mathrm{~S}_{9}$ & 2,88 & vs & 5,85 & 1136,87 & ** \\
\hline 11. & $\mathrm{~S}_{8} \mathrm{VS} \mathrm{S} 9$ & 4,04 & vs & 7,65 & 1257,85 & ** \\
\hline 12. & $\left(\mathrm{k}_{1}, \mathrm{k}_{2}, \mathrm{k}_{3}\right)$ vs $\left(\mathrm{k}_{4}, \mathrm{k}_{5}, \mathrm{k}_{6}\right),\left(\mathrm{k}_{7}, \mathrm{k}_{8}, \mathrm{k}_{9}\right)$ & 2,00 & vs & 3,34 & 699,93 & $* *$ \\
\hline
\end{tabular}




\begin{tabular}{|c|c|c|c|c|c|c|}
\hline 13. & $\left(\mathrm{k}_{4}, \mathrm{k}_{5}, \mathrm{k}_{6}\right)$ vs $\left(\mathrm{k}_{7}, \mathrm{k}_{8}, \mathrm{k}_{9}\right)$ & 2,87 & vs & 3,82 & 263,10 & $* *$ \\
\hline 14. & $\mathrm{k}_{1}$ vs $\mathrm{k}_{2}, \mathrm{k}_{3}$ & 0,97 & vs & 2,51 & 307,81 & $* *$ \\
\hline 15. & $\mathrm{k}_{2} \mathrm{vs} \mathrm{k}_{3}$ & 1,76 & vS & 3,27 & 219,79 & $* *$ \\
\hline 16. & $\mathrm{k}_{4} \mathrm{vs}_{5}, \mathrm{k}_{6}$ & 1,39 & vs & 3,60 & 630,55 & $* *$ \\
\hline 17. & $\mathrm{k}_{5} \mathrm{vs} \mathrm{k}_{6}$ & 2,29 & vS & 4,92 & 665,69 & $* *$ \\
\hline 18. & $\mathrm{k}_{7} \mathrm{vs} \mathrm{k}_{8}, \mathrm{k}_{9}$ & 2,02 & vS & 4,72 & 941,93 & $* *$ \\
\hline 19. & $\mathrm{k}_{8}$ vs $\mathrm{k}_{9}$ & 2,83 & vS & 6,62 & 1388,91 & $* *$ \\
\hline 20. & $\left(a_{1}, a_{2}, a_{3}\right)$ vs $\left(a_{4}, a_{5}, a_{6}\right),\left(a_{7}, a_{8}, a_{9}\right)$ & 2,34 & vs & 3,85 & 884,03 & $* *$ \\
\hline 21. & $\left(a_{4}, a_{5}, a_{6}\right)$ vs $\left(a_{7}, a_{8}, a_{9}\right)$ & 3,31 & vs & 4,39 & 341,89 & $* *$ \\
\hline 22. & $\mathrm{a}_{1} \mathrm{vs} \mathrm{a}_{2}, \mathrm{a}_{3}$ & 0,98 & vs & 3,01 & 530,38 & $* *$ \\
\hline 23. & $\mathrm{a}_{2} \mathrm{vs} \mathrm{a}_{3}$ & 2,36 & vs & 3,67 & 165,37 & $* *$ \\
\hline 24. & $\mathrm{a}_{4}$ vs $\mathrm{a}_{5}, \mathrm{a}_{6}$ & 1,58 & vs & 4,17 & 859,63 & $* *$ \\
\hline 25. & $\mathrm{a}_{5} \mathrm{vs} \mathrm{a}_{6}$ & 2,89 & vs & 5,44 & 628,20 & $* *$ \\
\hline 26. & $\mathrm{a}_{7} \mathrm{vs} \mathrm{a}_{8}, \mathrm{a}_{9}$ & 1,93 & vs & 5,63 & 1763,42 & $* *$ \\
\hline 27. & $\mathrm{a}_{8} \mathrm{vs} \mathrm{a}_{9}$ & 4,03 & vs & 7,23 & 989,27 & $* *$ \\
\hline 28. & $\left(c_{1}, c_{2}, c_{3}\right)$ vs $\left(c_{4}, c_{5}, c_{6}\right),\left(c_{7}, c_{8}, c_{9}\right)$ & 2,66 & vs & 4,06 & 755,91 & $* *$ \\
\hline 29. & $\left(c_{4}, c_{5}, c_{6}\right)$ vs $\left(c_{7}, c_{8}, c_{9}\right)$ & 3,53 & vs & 4,59 & 331,48 & $* *$ \\
\hline 30. & $\mathrm{c}_{1} \mathrm{VS} \mathrm{c}_{2}, \mathrm{c}_{3}$ & 1,23 & vs & 3,38 & 597,74 & $* *$ \\
\hline 31. & $\mathrm{c}_{2}$ VS $\mathrm{c}_{3}$ & 2,62 & vs & 4,14 & 224,67 & $* *$ \\
\hline 32. & $\mathrm{c}_{4} \mathrm{VS} \mathrm{c}_{5}, \mathrm{c}_{6}$ & 1,59 & vs & 4,49 & 1083,30 & $* *$ \\
\hline 33. & $\mathrm{c}_{5} \mathrm{VS} \mathrm{c}_{6}$ & 3,16 & vs & 5,83 & 686,99 & $* *$ \\
\hline 34. & $\mathrm{c}_{7} \mathrm{VS} \mathrm{c}_{8}, \mathrm{c}_{9}$ & 2,60 & vS & 5,59 & 1152,87 & $* *$ \\
\hline 35. & $\mathrm{c}_{8}$ VS $\mathrm{c}_{9}$ & 4,36 & VS & 6,83 & 587,81 & $* *$ \\
\hline
\end{tabular}

Keterangan : $* *=$ berbeda sangat nyata

Tabel 2. Hasil Uji Kontras Ortogonal Pertambahan Jumlah Daun (Helai) Tanaman Stroberi Umur 9 MST

\begin{tabular}{|c|c|c|c|c|c|c|}
\hline No & Perlakuan & Rata-rata & & & itung & \\
\hline 1. & $\mathrm{~s}$ vs $\mathrm{k}, \mathrm{a}, \mathrm{c}$ & 2,96 & VS & 2,54 & 226,71 & $* *$ \\
\hline 2. & $\mathrm{k}$ vs a, c & 2,19 & vS & 2,62 & 61,93 & $* *$ \\
\hline 3. & a vs c & 2,55 & vS & 2,69 & 16,07 & $* *$ \\
\hline 4. & $\left(\mathrm{~s}_{1}, \mathrm{~S}_{2}, \mathrm{~S}_{3}\right)$ vs $\left(\mathrm{s}_{4}, \mathrm{~S}_{5}, \mathrm{~S}_{6}\right),\left(\mathrm{s}_{7}, \mathrm{~S}_{8}, \mathrm{~S}_{9}\right)$ & 2,47 & vs & 3,21 & 200,64 & $* *$ \\
\hline 5. & $\left(\mathrm{~S}_{4}, \mathrm{~S}_{5}, \mathrm{~S}_{6}\right)$ vs $\left(\mathrm{S}_{7}, \mathrm{~S}_{8}, \mathrm{~S}_{9}\right)$ & 2,86 & VS & 3,56 & 133,93 & $* *$ \\
\hline 6. & $\mathrm{~S}_{1}$ VS $\mathrm{S}_{2}, \mathrm{~S}_{3}$ & 1,58 & VS & 2,92 & 219,43 & $* *$ \\
\hline 7. & $\mathrm{~S}_{2}$ VS $\mathrm{S}_{3}$ & 2,50 & vS & 3,33 & 64,29 & $* *$ \\
\hline 8. & $\mathrm{~S}_{4}$ VS $\mathrm{S}_{5}, \mathrm{~S}_{6}$ & 1,92 & VS & 3,33 & 247,71 & $* *$ \\
\hline 9. & $\mathrm{~S}_{5} \mathrm{VS} \mathrm{S}_{6}$ & 2,92 & VS & 3,75 & 64,29 & $* *$ \\
\hline 10. & $\mathrm{~S}_{7} \mathrm{VSS}_{8}, \mathrm{~S}_{9}$ & 2,58 & vs & 4,04 & 262,50 & $* *$ \\
\hline 11. & $\mathrm{~S}_{8}$ VS S9 & 3,58 & VS & 4,50 & 77,79 & $* *$ \\
\hline 12. & $\left(\mathrm{k}_{1}, \mathrm{k}_{2}, \mathrm{k}_{3}\right)$ vs $\left(\mathrm{k}_{4}, \mathrm{k}_{5}, \mathrm{k}_{6}\right),\left(\mathrm{k}_{7}, \mathrm{k}_{8}, \mathrm{k}_{9}\right)$ & 1,94 & VS & 2,60 & 157,79 & $* *$ \\
\hline 13. & $\left(\mathrm{k}_{4}, \mathrm{k}_{5}, \mathrm{k}_{6}\right)$ vs $\left(\mathrm{k}_{7}, \mathrm{k}_{8}, \mathrm{k}_{9}\right)$ & 2,33 & vs & 2,86 & 77,36 & $* *$ \\
\hline 14. & $\mathrm{k}_{1} \mathrm{vs} \mathrm{k}_{2}, \mathrm{k}_{3}$ & 1,17 & vs & 2,33 & 168,00 & $* *$ \\
\hline 15. & $\mathrm{k}_{2} \mathrm{Vs} \mathrm{k}_{3}$ & 1,92 & VS & 2,75 & 64,29 & $* *$ \\
\hline 16. & $\mathrm{k}_{4}$ vs $\mathrm{k}_{5}, \mathrm{k}_{6}$ & 1,50 & vs & 2,75 & 192,86 & $* *$ \\
\hline 17. & $\mathrm{k}_{5} \mathrm{vs} \mathrm{k}_{6}$ & 2,25 & vS & 3,25 & 92,57 & $* *$ \\
\hline 18. & $\mathrm{k}_{7} \mathrm{vs} \mathrm{k}_{8}, \mathrm{k}_{9}$ & 2,08 & vs & 3,25 & 168,00 & $* *$ \\
\hline 19. & $\mathrm{k}_{8} \mathrm{Vs} \mathrm{k}_{9}$ & 2,58 & VS & 3,92 & 164,57 & $* *$ \\
\hline 20. & $\left(a_{1}, a_{2}, a_{3}\right)$ vs $\left(a_{4}, a_{5}, a_{6}\right),\left(a_{7}, a_{8}, a_{9}\right)$ & 2,06 & vs & 2,79 & 200,64 & $* *$ \\
\hline 21. & $\left(a_{4}, a_{5}, a_{6}\right)$ vs $\left(a_{7}, a_{8}, a_{9}\right)$ & 2,58 & vS & 3,00 & 48,21 & $* *$ \\
\hline 22. & $\mathrm{a}_{1} \mathrm{vs} \mathrm{a}_{2}, \mathrm{a}_{3}$ & 1,42 & VS & 2,38 & 113,36 & $* *$ \\
\hline 23. & $\mathrm{a}_{2} \mathrm{vs} \mathrm{a}_{3}$ & 1,83 & vS & 2,92 & 108,64 & $* *$ \\
\hline 24. & $a_{4}$ vs $a_{5}, a_{6}$ & 1,67 & vs & 3,04 & 233,36 & $* *$ \\
\hline 25. & $\mathrm{a}_{5} \mathrm{vs} \mathrm{a}_{6}$ & 2,50 & VS & 3,58 & 108,64 & $* *$ \\
\hline 26. & 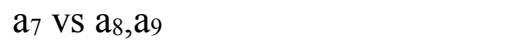 & 2,08 & VS & 3,46 & 233,36 & $* *$ \\
\hline 27. & $\mathrm{a}_{8} \mathrm{vs} \mathrm{a}_{9}$ & 3,00 & VS & 3,92 & 77,79 & $* *$ \\
\hline
\end{tabular}




\begin{tabular}{|c|c|c|c|c|c|c|}
\hline 28. & $\left(\mathrm{c}_{1}, \mathrm{c}_{2}, \mathrm{c}_{3}\right)$ vs $\left(\mathrm{c}_{4}, \mathrm{c}_{5}, \mathrm{c}_{6}\right),\left(\mathrm{c}_{7}, \mathrm{c}_{8}, \mathrm{c}_{9}\right)$ & 2,08 & vs & 2,99 & 301,79 & $* *$ \\
\hline 29. & $\left(\mathrm{c}_{4}, \mathrm{c}_{5}, \mathrm{c}_{6}\right)$ vs $\left(\mathrm{c}_{7}, \mathrm{c}_{8}, \mathrm{c}_{9}\right)$ & 2,58 & vs & 3,39 & 180,21 & $* *$ \\
\hline 30. & $\mathrm{c}_{1} \mathrm{vS} \mathrm{c}_{2}, \mathrm{c}_{3}$ & 1,17 & vs & 2,54 & 233,36 & $* *$ \\
\hline 31. & $\mathrm{c}_{2} \mathrm{vS} \mathrm{c}_{3}$ & 1,83 & vs & 3,25 & 185,79 & $* *$ \\
\hline 32. & $\mathrm{c}_{4} \mathrm{vs} \mathrm{c}_{5}, \mathrm{c}_{6}$ & 1,50 & vs & 3,13 & 325,93 & $* *$ \\
\hline 33. & $\mathrm{c}_{5} \mathrm{vs} \mathrm{c}_{6}$ & 2,67 & vs & 3,58 & 77,79 & $* *$ \\
\hline 34. & $\mathrm{c}_{7} \mathrm{vs} \mathrm{c}_{8}, \mathrm{c}_{9}$ & 2,67 & vs & 3,75 & 144,86 & $* *$ \\
\hline 35. & $\mathrm{c}_{8} \mathrm{Vs} \mathrm{c}_{9}$ & 3,17 & vs & 4,33 & 126,00 & $* *$ \\
\hline
\end{tabular}

Keterangan : $* *=$ berbeda sangat nyata

Tabel 3. Hasil Uji Kontras Ortogonal Jumlah Bunga (Bunga) Tanaman Stroberi

\begin{tabular}{|c|c|c|c|c|c|c|}
\hline No & Perlakuan & Rata-rata & & & itung & \\
\hline 1. & s vs k, a, c & 6,15 & vs & 5,95 & 2,15 & tn \\
\hline 2. & $\mathrm{k}$ vs a, c & 4,58 & vs & 6,46 & 107,61 & ** \\
\hline 3. & a vs c & 6,02 & vs & 6,89 & 25,90 & $* *$ \\
\hline 4. & $\left(\mathrm{~s}_{1}, \mathrm{~S}_{2}, \mathrm{~S}_{3}\right)$ vs $\left(\mathrm{s}_{4}, \mathrm{~S}_{5}, \mathrm{~S}_{6}\right),\left(\mathrm{s}_{7}, \mathrm{~S}_{8}, \mathrm{~s}_{9}\right)$ & 4,66 & vs & 6,90 & 77,94 & $* *$ \\
\hline 5. & $\left(\mathrm{~s}_{4}, \mathrm{~S}_{5}, \mathrm{~s}_{6}\right)$ vs $\left(\mathrm{s}_{7}, \mathrm{~s}_{8}, \mathrm{~s}_{9}\right)$ & 6,50 & vs & 7,30 & 7,38 & $* *$ \\
\hline 6. & $\mathrm{~S}_{1} \mathrm{VS} \mathrm{S}_{2}, \mathrm{~S}_{3}$ & 3,17 & vs & 5,40 & 25,87 & $* *$ \\
\hline 7. & $\mathrm{~s}_{2} \mathrm{vs} \mathrm{s}_{3}$ & 4,56 & vs & 6,25 & 11,14 & $* *$ \\
\hline 8. & $\mathrm{~S}_{4}$ VS $\mathrm{S}_{5}, \mathrm{~S}_{6}$ & 5,78 & vs & 6,86 & 6,07 & $*$ \\
\hline 9. & $\mathrm{~S}_{5} \mathrm{VS} \mathrm{S}_{6}$ & 6,33 & vs & 7,39 & 4,32 & $*$ \\
\hline 10. & $\mathrm{~S}_{7} \mathrm{VS} \mathrm{S}_{8}, \mathrm{~S}_{9}$ & 6,25 & vs & 7,82 & 12,75 & $* *$ \\
\hline 11. & $\mathrm{~S}_{8}$ VS $\mathrm{S}_{9}$ & 7,17 & vs & 8,47 & 6,61 & $*$ \\
\hline 12. & $\left(\mathrm{k}_{1}, \mathrm{k}_{2}, \mathrm{k}_{3}\right)$ vs $\left(\mathrm{k}_{4}, \mathrm{k}_{5}, \mathrm{k}_{6}\right),\left(\mathrm{k}_{7}, \mathrm{k}_{8}, \mathrm{k}_{9}\right)$ & 2,85 & vs & 5,98 & 151,60 & $* *$ \\
\hline 13. & $\left(\mathrm{k}_{4}, \mathrm{k}_{5}, \mathrm{k}_{6}\right)$ vs $\left(\mathrm{k}_{7}, \mathrm{k}_{8}, \mathrm{k}_{9}\right)$ & 5,03 & vs & 6,93 & 41,95 & $* *$ \\
\hline 14. & $\mathrm{k}_{1} \mathrm{vs} \mathrm{k}_{2}, \mathrm{k}_{3}$ & 1,50 & vs & 3,53 & 21,28 & $* *$ \\
\hline 15. & $\mathrm{k}_{2} \mathrm{vs} \mathrm{k}_{3}$ & 3,25 & vs & 3,81 & 1,20 & tn \\
\hline 16. & $\mathrm{k}_{4} \mathrm{vs} \mathrm{k}_{5}, \mathrm{k}_{6}$ & 4,33 & vs & 5,38 & 5,61 & $*$ \\
\hline 17. & $\mathrm{k}_{5} \mathrm{vs} \mathrm{k}_{6}$ & 5,19 & vs & 5,56 & 0,51 & tn \\
\hline 18. & $\mathrm{k}_{7} \mathrm{vs} \mathrm{k}_{8}, \mathrm{k}_{9}$ & 6,14 & vs & 7,32 & 7,21 & $* *$ \\
\hline 19. & $\mathrm{k}_{8}$ vs $\mathrm{k}_{9}$ & 6,89 & vs & 7,75 & 2,88 & tn \\
\hline 20. & $\left(a_{1}, a_{2}, a_{3}\right)$ vs $\left(a_{4}, a_{5}, a_{6}\right),\left(a_{7}, a_{8}, a_{9}\right)$ & 3,90 & vs & 7,09 & 157,95 & $* *$ \\
\hline 21. & $\left(\mathrm{a}_{4}, \mathrm{a}_{5}, \mathrm{a}_{6}\right)$ vs $\left(\mathrm{a}_{7}, \mathrm{a}_{8}, \mathrm{a}_{9}\right)$ & 5,47 & vs & 8,70 & 121,58 & $* *$ \\
\hline 22. & $\mathrm{a}_{1} \mathrm{vs} \mathrm{a}_{2}, \mathrm{a}_{3}$ & 2,92 & vs & 4,39 & 11,22 & $* *$ \\
\hline 23. & $\mathrm{a}_{2}$ vs $\mathrm{a}_{3}$ & 4,22 & vs & 4,56 & 0,43 & tn \\
\hline 24. & $\mathrm{a}_{4} \mathrm{vs} \mathrm{a}_{5}, \mathrm{a}_{6}$ & 4,56 & vS & 5,93 & 9,78 & $* *$ \\
\hline 25. & $\mathrm{a}_{5} \mathrm{vs} \mathrm{a}_{6}$ & 5,53 & vs & 6,33 & 2,52 & tn \\
\hline 26. & $\mathrm{a}_{7} \mathrm{vs}_{\mathrm{a}}, \mathrm{a}_{9}$ & 7,22 & vs & 9,44 & 25,55 & $* *$ \\
\hline 27. & $\mathrm{a}_{8} \mathrm{vs} \mathrm{a}_{9}$ & 8,67 & vs & 10,22 & 9,39 & $* *$ \\
\hline 28. & $\left(c_{1}, c_{2}, c_{3}\right)$ vs $\left(c_{4}, c_{5}, c_{6}\right),\left(c_{7}, c_{8}, c_{9}\right)$ & 5,54 & vs & 7,56 & 63,54 & $* *$ \\
\hline 29. & $\left(\mathrm{c}_{4}, \mathrm{c}_{5}, \mathrm{c}_{6}\right)$ vs $\left(\mathrm{c}_{7}, \mathrm{c}_{8}, \mathrm{c}_{9}\right)$ & 6,06 & vs & 9,06 & 104,14 & $* *$ \\
\hline 30. & $\mathrm{c}_{1} \mathrm{VS} \mathrm{c}_{2}, \mathrm{c}_{3}$ & 3,50 & vS & 6,56 & 48,31 & $* *$ \\
\hline 31. & $\mathrm{c}_{2} \mathrm{VS} \mathrm{c}_{3}$ & 6,44 & vs & 6,67 & 0,19 & tn \\
\hline 32. & $\mathrm{c}_{4} \mathrm{VS} \mathrm{c}_{5}, \mathrm{c}_{6}$ & 5,17 & vS & 6,51 & 9,39 & $* *$ \\
\hline 33. & $\mathrm{c}_{5} \mathrm{VS} \mathrm{c}_{6}$ & 6,28 & vs & 6,75 & 0,87 & tn \\
\hline 34. & $\mathrm{c}_{7} \mathrm{VS} \mathrm{c}_{8}, \mathrm{c}_{9}$ & 8,00 & vS & 9,58 & 12,97 & $* *$ \\
\hline 35. & $\mathrm{c}_{8} \mathrm{VS} \mathrm{c}_{9}$ & 8,08 & vs & 11,08 & 34,93 & $* *$ \\
\hline
\end{tabular}

Keterangan $: *=$ berbeda nyata $; * *=$ berbeda sangat nyata $; \mathrm{tn}=$ berbeda tidak nyata

Tinggi Tanaman. Tabel 1 menunjukkan bahwa kelompok perlakuan POC sapi (s) menghasilkan rata-rata pertambahan tinggi tanaman stroberi tertinggi pada umur 9 MST
$(3,72 \mathrm{~cm})$ dan sangat berbeda nyata dengan kelompok POC lainnya (Kambing, Ayam dan Kelinci). Grup POC Sapi dengan konsentrasi 6 $\mathrm{mL} \mathrm{L}{ }^{-1}$ air $\left(\mathrm{S}_{7}, \mathrm{~S}_{8}, \mathrm{~S} 9\right)$ menghasilkan rata-rata 
pertambahan tinggi tanaman tertinggi $(4,86$ $\mathrm{cm})$ dan sangat berbeda nyata dibandingkan dengan konsentrasi lainnya (konsentrasi 2 dan $4 \mathrm{~mL} \mathrm{~L}^{-1}$ air). Sedangkan POC sapi pada konsentrasi $6 \mathrm{~mL} \mathrm{~L}^{-1}$ air dengan penambahan urine sapi $50 \mathrm{~mL} \mathrm{~L}^{-1}$ air (s9) menghasilkan ratarata pertambahan tinggi tanaman tertinggi $(7,65 \mathrm{~cm})$ dan sangat berbeda nyata dibandingkan dengan konsentrasi urine sapi lainnya.

Jumlah Daun. Pertambahan jumlah daun tanaman pada umur 9 MST dan sidik ragam menunjukkan bahwa perlakuan berbagai jenis dan konsentrasi pupuk organik cair dengan berbagai konsentrasi urine sapi berpengaruh sangat nyata terhadap pertambahan jumlah daun tanaman umur 9 MST. Hasil uji kontras ortogonal disajikan pada Tabel 2. Tabel 2 menunjukkan bahwa kelompok perlakuan POC sapi (s) menghasilkan rata-rata pertambahan jumlah daun tanaman stroberi terbanyak pada umur 9 MST (2,96 helai) dan berbeda sangat nyata dengan kelompok POC lainnya (Kambing, Ayam dan Kelinci). Grup POC Sapi dengan konsentrasi $6 \mathrm{~mL} \mathrm{~L}^{-1}$ air $\left(\mathrm{s}_{7}, \mathrm{~S}_{8}, \mathrm{~S}_{9}\right)$ menghasilkan rata-rata pertambahan jumlah daun tanaman terbanyak (3,56 helai) dan berbeda sangat nyata dibandingkan dengan konsentrasi lainnya (konsentrasi 2 dan $4 \mathrm{~mL} \mathrm{~L}^{-1}$ air). Sedangkan POC sapi pada konsentrasi $6 \mathrm{~mL} \mathrm{~L}^{-1}$ air dengan penambahan urine sapi $50 \mathrm{~mL} \mathrm{~L}^{-1}$ air (s9) menghasilkan ratarata pertambahan jumlah daun tanaman terbanyak (4,50 helai) dan berbeda sangat nyata dibandingkan dengan konsentrasi $6 \mathrm{~mL}$ $\mathrm{L}^{-1}$ air pada berbagai konsentrasi penambahan urine sapi lainnya.

Jumlah Bunga. Jumlah bunga dan sidik ragamnya menunjukkan bahwa perlakuan berbagai jenis dan konsentrasi pupuk organik cair dengan berbagai konsentrasi urine sapi berpengaruh sangat nyata terhadap jumlah bunga. Hasil uji kontras ortogonal disajikan pada Tabel 3. Tabel 3 menunjukkan bahwa kelompok perlakuan POC Kelinci (c) menghasilkan rata-rata jumlah bunga terbanyak $(6,89$ bunga) dan berbeda sangat nyata dengan kelompok POC lainnya (Kambing dan Ayam), tetapi berbeda tidak nyata dengan kelompok perlakuan POC Sapi (s). Grup POC kelinci dengan konsentrasi 6 $\mathrm{mL} \mathrm{L}{ }^{-1}$ air $\left(\mathrm{c}_{7}, \mathrm{c}_{8}, \mathrm{c}_{9}\right)$ menghasilkan rata-rata jumlah bunga terbanyak ( 9,06 bunga) dan berbeda sangat nyata dibandingkan dengan konsentrasi lainnya (konsentrasi 2 dan $4 \mathrm{~mL} \mathrm{~L}^{-}$ 1 air). Sedangkan POC kelinci pada konsentrasi $6 \mathrm{~mL} \mathrm{~L}^{-1}$ air dengan penambahan urine sapi $50 \mathrm{~mL} \mathrm{~L}^{-1}$ air ( $\left.\mathrm{c}_{9}\right)$ menghasilkan rata-rata jumlah bunga terbanyak $(11,08$ bunga) dan berbeda sangat nyata dibandingkan dengan konsentrasi $6 \mathrm{~mL} \mathrm{~L}^{-1}$ air pada berbagai konsentrasi penambahan urine sapi lainnya.

\section{PEMBAHASAN}

Analisis statistik menunjukkan bahwa kelompok perlakuan dengan Pupuk Organik Cair Sapi pada konsentrasi $6 \mathrm{~mL} \mathrm{~L}^{-1}$ air dengan penambahan urine sapi $50 \mathrm{~mL} \mathrm{~L}^{-1}$ air (s9) menghasilkan pertumbuhan vegetatif yang lebih baik dalam hal tinggi tanaman dan jumlah daun yang lebih banyak pada tanaman stroberi hingga umur 9 MST dibandingkan perlakuan lain. Hal ini diduga disebabkan karena kandungan yang dimiliki oleh Pupuk Organik Cair Sapi yang digunakan, kotoran sapi yang dijadikan bahan utama untuk pupuk organik cair memiliki keragaman bahanbahan makanan yang lebih tinggi, selain itu kotoran sapi (feses) telah bercampur dengan urine sapi yang melalui proses fermentasi akan menghasilkan hormon IAA yang merupakan hormon jenis auksin. Hormon inilah yang memberikan respon bagi perkembangan sel-sel untuk kepentingan pertumbuhan, sehingga hasil menunjukkan bahwa tinggi tanaman dan jumlah daun yang diperoleh dari penggunaan pupuk organik cair sapi adalah yang terbaik.

Hasil yang menunjukkan jumlah daun yang terbaik oleh perlakuan pupuk organic cair sapi, hal ini berhubungan dengan pertumbuhan batang atau tinggi tanaman dimana batang tersusun dari ruas yang merentang diantara buku-buku batang tempat melekatnya daun. Jumlah buku dan ruas sama dengan jumlah daun. Sehingga dengan bertambah panjangnya batang akan menyebabkan jumlah daun yang terbentuk juga semakin banyak. Pemanjangan batang (pertumbuhan tinggi tanaman) terjadi sebagai akibat dari pemanjangan dan pertambahan ruas pada batang. Pemanjangan 
ruas terjadi karena adanya aktivitas pembelahan sel yang pada akhirnya menyebabkan pertambahan jumlah sel. Proses ini tidak lepas dari aktivitas fisiologi dalam tubuh tanaman yang dipengaruhi oleh adanya pengaruh hormon yang diberikan tubuh tanaman. Seperti yang dikemukakan oleh Gardner et al. (1991) menyatakan bahwa pertumbuhan tinggi batang terjadi di dalam meristem interkalar dari ruas. Ruas itu memanjang sebagai akibat meningkatnya jumlah sel dan terutama karena adanya pemanjangan sel yang dapat menyebabkan peningkatan sampai $25 \mathrm{~cm}$ atau lebih. Pertumbuhan karena pembelahan sel terjadi pada dasar ruas (interkalar).

Selain itu perlakuan ini bersinergis dengan penambahan urine sapi pada konsentrasi 50 $\mathrm{mL} \mathrm{L} \mathrm{L}^{-1}$ air yang juga telah difermentasikan menyebabkan konsentrasi IAA yang diberikan mampu secara optimal memacu pertumbuhan tanaman. Mengenai kandungan hormon IAA pada urine sapi tersebut disebutkan oleh Solikun dan Masdiko (2005), bahwa fermentasi urine sapi secara ilmiah mengandung zat pengatur tumbuh yaitu auksin golongan IAA. Sedangkan mekanisme kerja hormon tersebut dijelaskan oleh Abidin (1992), bahwa auksin menginisiasi pemanjangan sel dengan cara mempengaruhi pengendoran/pelenturan dinding sel. Auksin memacu protein tertentu yang ada di membran plasma sel tumbuhan untuk memompa ion $\mathrm{H}^{+}$ ke dinding sel. Ion $\mathrm{H}^{+}$ini mengaktifkan enzim tertentu sehingga memutuskan beberapa ikatan silang hidrogen rantai molekul selulosa penyusun dinding sel. Sel tumbuhan kemudian memanjang akibat air yang masuk secara osmosis. Setelah pemanjangan ini, sel terus tumbuh dengan mensintesis kembali material dinding sel dan sitoplasma.

Selain hormon yang dikandung oleh pupuk organik cair sapi dan urine sapi yang dapat memacu pertumbuhan tanaman, unsur hara yang dikandungnya juga mempercepat pertumbuhan vegetatif tanaman. Pupuk organik cair sapi mengandung unsur $\mathrm{N}, \mathrm{P}, \mathrm{K}$ yang lebih tinggi dibanding pupuk organik cair lainnya tetapi masih lebih rendah bila dibanding pupuk organik cair ayam. Diduga yang menyebabkan hasil tinggi tanaman dan jumlah daun yang lebih tinggi pada perlakuan pupuk organik cair sapi dibanding perlakuan lainnya oleh karena unsur hara yang dikandungnya juga lebih tinggi, terutama pengaruh unsur $\mathrm{N}$ yang lebih tinggi, dimana unsur $\mathrm{N}$ merupakan unsur yang penting untuk pertumbuhan vegetatif tanaman. Nitrogen merupakan penyusun protein dan protein merupakan penyusun utama protoplasma yang berfungsi sebagai pusat proses metabolisme dalam tanaman yang selanjutnya akan memacu pembelahan dan pemanjangan sel tanaman. Selain unsur hara makro pupuk organik cair juga mengandung unsur hara mikro yang juga menyebabkan terpacunya pembelahan sel. Hal tersebut seperti yang dikemukakan oleh Indrakusuma (2000) dan Salisbury \& Ross (1995) menyatakan bahwa pupuk organik cair selain mengandung nitrogen yang menyusun dari semua protein, asam nukleat dan klorofil juga mengandung unsur hara mikro antara lain unsur Mn, Zn, Fe, S, B, Ca dan Mg. Unsur hara mikro tersebut berperan sebagai katalisator dalam proses sintesis protein dan pembentukan klorofil. Seperti halnya juga yang dikemukakan oleh Poerwowidodo (1992) bahwa protein merupakan penyusun utama protoplasma yang berfungsi sebagai pusat proses metabolisme dalam tanaman yang selanjutnya akan memacu pembelahan dan pemanjangan sel. Unsur hara nitrogen dan unsur hara mikro tersebut berperan sebagai penyusun klorofil sehingga meningkatkan aktivitas fotosintesis tersebut akan menghasilkan fotosintat yang mengakibatkan perkembangan pada jaringan meristematis daun.

Selanjutnya pada hasil uji kontras ortogonal pada saat memasuki umur berbunga. Pemberian pupuk organik cair Kelinci pada konsentrasi $6 \mathrm{~mL} \mathrm{~L}^{-1}$ air dengan penambahan urine sapi $50 \mathrm{~mL} \mathrm{~L}^{-1}$ air (c9) menghasilkan pertumbuhan yang lebih baik, dalam hal ini jumlah bunga. Hal ini diduga disebabkan akibat pengaruh dari karakter kotoran yang dihasilkan oleh kelinci yang merupakan bahan utama dalam pupuk organic cair kelinci. Pada kotoran lunak kelinci diselaputi mukosa yang mengandung bahan protein tinggi $(28,5 \%)$. 
Hal inilah yang diduga dapat menghasilkan jumlah bunga yang lebih baik dibandingkan dengan pemberian perlakuan lainnya. Dijelaskan oleh Knutson et al., (1977) dalam Sajimin dkk., (1991) tentang penyebab kandungan protein yang tinggi dalam kotoran kelinci, bahwa tingginya protein ini disebabkan populasi mikroba dalam sekum yang sangat aktif dalam memanfaatkan nitrogen yang masuk sekum dan protein mikroba ini turut menyumbang tingginya kadar protein dalam kotoran. Dijelaskan pula oleh Uden dan Van Soest (1982) dalam Farrell dan Raharjo (1984) bahwa sistem pencernaan pada kelinci mencerna serat kasar lebih rendah karena waktu transit yang cepat dalam saluran pencernaan. Kemudian komposisi kotoran kelinci lunak dan diselaputi mukosa yang mengandung bahan protein tinggi $(28,5 \%)$ sedangkan pada kotoran kerasnya 9,2\%.

Hasil penelitian menunjukkan bahwa pupuk organik cair kelinci memberikan hasil yang lebih tinggi pada perkembangan masa berbunga dibandingkan dengan perlakuan pupuk organik lainnya seperti bila dibandingkan dengan pupuk organik cair kambing. Hal ini juga diduga karena kandungan unsur hara $\mathrm{P}$ yang dikandung $\mathrm{POC}$ kelinci yang lebih tinggi dibandingkan POC kambing selain disebabkan karena kandungan protein pupuk organik kelinci yang tinggi. Menurut Abidin (1992) pada fase generatif mulai dari pembungaan sampai menghasilkan buah, unsur $\mathrm{P}$ dan $\mathrm{K}$ yang paling banyak dibutuhkan tanaman dan unsur lainnya sebagai pendukung.

Hasil penelitian menunjukkan bahwa penggunaan pupuk organik cair sapi dan kelinci memberikan hasil yang lebih baik terhadap pertumbuhan vegetatif dibanding dengan pupuk organik ayam. Apabila dilihat dari hasil analisis kandungan hara, pupuk organik cair ayam mengandung unsur hara $\mathrm{N}$, $\mathrm{P}$ dan $\mathrm{K}$ yang tertinggi, akan tetapi tidak memberikan respon pertumbuhan dan produksi tanaman yang lebih baik dibandingkan perlakuan POC lainnya. Hal ini diduga karena terjadi penguapan atau kehilangan unsur-unsur hara yang dikandung dalam pupuk organik cair ayam yang dapat terjadi saat proses penyimpanan, pengaplikasian pupuk organik cair, pengadukan larutan hingga setelah diaplikasikan pada tanaman. Pada pengaplikasian larutan diteteskan pada media disamping perakaran tanaman dan diduga juga karena media arang sekam yang bersifat porous sehingga unsur hara yang diserap yang dikandung oleh pupuk organik cair ayam menjadi berkurang. Kotoran ayam termasuk dalam kategori sebagai pupuk panas sehingga mudah sekali matang dan terurai sehingga dengan cepat unsur-unsurnya bisa hilang. Menurut Lingga dan Marsono (2007) menyatakan bahwa pupuk panas adalah pupuk yang penguraiannya berjalan sangat cepat sehingga terbentuk panas. Kelemahan dari pupuk panas ialah mudah menguap karena bahan organiknya tidak terurai secara sempurna sehingga banyak yang berubah menjadi gas. Pupuk kotoran kelinci memberikan hasil yang lebih tinggi dibanding kotoran ayam sesuai dengan penelitian yang dilakukan oleh Rahardjo pada beberapa jenis sayuran seperti kubis, jagung sayur, buncis, kacang merah dan kentang menunjukkan bahwa penggunaan pupuk kotoran kelinci memberikan hasil yang lebih tinggi dibandingkan dengan kotoran ayam (Anonim, 2006).

Pupuk organik cair serta urin sapi yang diberikan dengan konsentrasi yang tertinggi memberikan respon yang lebih baik terhadap pertumbuhan. Respon tanaman stroberi terhadap pemberian pupuk organik cair memberikan hasil yang meningkat pada konsentrasi yang tertinggi $6 \mathrm{~mL} \mathrm{~L}^{-1}$ air dengan penambahan urine sapi $50 \mathrm{~mL} \mathrm{~L}^{-1}$ air. Hal ini menunjukkan bahwa semakin tinggi konsentrasi pupuk yang diberikan maka kandungan unsur hara yang diserap untuk pertumbuhan tanaman stroberi akan semakin tinggi yang ditunjukkan oleh pertumbuhan lebih baik pada konsentrasi tersebut. Konsentrasi tersebut belum sampai pada konsentrasi yang berlebihan karena tidak terjadinya gangguan pada pertumbuhan tanaman dan kemungkinan dapat dilakukan penambahan konsentrasi hingga mencapai titik optimal bagi tanaman menerima konsentrasi 
pupuk organik cair dan urine sapi tersebut. Pemberian pupuk pada konsentrasi yang tinggi sampai batas tertentu akan menyebabkan hasil semakin meningkat, dan pada konsentrasi yang melebihi batas tertentu pula akan menyebabkan hasil menjadi menurun. Menurut Harjadi (1991), pada tingkat yang lebih tinggi, walaupun gejala-gejala defisiensi belum tampak, tanaman akan memberikan tanggapan terhadap pemupukan dengan kenaikan hasil atau penampilannya. Dengan tersedianya unsur hara yang lengkap dan jumlah yang sesuai dengan kebutuhan tanaman akan dapat merangsang pertumbuhan dan perkembangan bagian-bagian vegetatif tanaman.

\section{KESIMPULAN}

1. Pupuk organik cair sapi memberikan hasil terbaik pada tinggi tanaman dan jumlah daun tanaman stroberi di antara pupuk organik cair dari kotoran ternak lainnya (POC kambing, ayam, dan kelinci), sedangkan pupuk organik cair kelinci memberikan hasil terbaik pada jumlah bunga di antara pupuk organik cair dari kotoran ternak lainnya (POC sapi, kambing, dan ayam).

2. Penambahan urine sapi yang difermentasi $50 \mathrm{~mL} \mathrm{~L}^{-1}$ memberikan hasil terbaik terhadap pertumbuhan tanaman stroberi di antara urine sapi yang difermentasi $25 \mathrm{~mL}$ $\mathrm{L}^{-1}$ dan tanpa urine. Tanpa urine sapi memberikan pertumbuhan yang terendah.

3. Pupuk organik cair sapi pada konsentrasi tertinggi $6 \mathrm{~mL} \mathrm{~L}^{1}$ dengan penambahan urine sapi yang difermentasi pada konsentrasi tertinggi $50 \quad \mathrm{~mL}^{-1}$ memberikan hasil terbaik pada tinggi tanaman $(7,65 \mathrm{~cm})$ dan jumlah daun $(4,50$ helai) di antara penambahan urine sapi lainnya. Sedangkan pupuk organik cair kelinci pada konsentrasi tertinggi $6 \mathrm{~mL} \mathrm{~L}^{-1}$ dengan penambahan urine sapi yang difermentasi pada konsentrasi yang tertinggi $50 \mathrm{~mL} \mathrm{~L}^{-1}$ memberikan hasil terbaik pada jumlah bunga ( 11,08 bunga) di antara penambahan urine sapi lainnya.

Perlu dilakukan penelitian lebih lanjut mengenai penggunaan pupuk organik cair dari kotoran ternak dan penambahan urine sapi yang difermentasi dengan menggunakan konsentrasi yang lebih tinggi.

\section{DAFTAR PUSTAKA}

Abidin. 1992. Dasar Pengetahuan Ilmu Tanaman. Bandung: Angkasa.

Aswita AP. 2007. Analisis Usaha Tani Stroberi. http://repository.usu.ac.id. Diakses 23 Februari 2012.

Badan Pusat Statistik. 2011. Perkembangan Beberapa Indikator Utama SosialEkonomi Indonesia.http://www.bps.go.id. Diakses 5 Februari 2012.

Farrell DJ, dan Raharjo YC. 1984. The Potensial for Meat Production from Rabbits. Bogor: Puslibangnak.

Gardner FP, Pearce RB, and Mitchell RL. 1991. Physiology of Crop Plants (Fisiologi Tanaman Budidaya). Jakarta: Universitas Indonesia Press.

Harjadi SS. 1991. Pengantar Agronomi. Jakarta: Gramedia.

Indrakusuma. 2000. Proposal Pupuk Organik Cair Supra Alam Lestari. Yogyakarta: PT Surya Pratama Alam.

Lingga P dan Marsono. 2007. Petunjuk Penggunaan Pupuk. Jakarta: Penebar Swadaya.

Mardalena. 2007. Respon Pertumbuhan dan Produksi Tanaman Mentimun (Cucumis sativus L.) Terhadap Urine Sapi yang Telah Mengalami Perbedaan Lama Fermentasi. Medan: Fakultas Pertanian Universitas Sumatera Utara.

Noor N, Raharjo YC, Murtiyeni, dan Haryani R. 1996. Pemanfaatan Usahatani Sayuran Untuk Pengembangan Agribisnis Kelinci di Sulawesi Selatan. Laporan Penelitian. Balitnak Ciawi-Balittan Maros. Bogor: Puslitbangtan.

Parman S. 2007. Pengaruh Pemberian Pupuk Organik Cair terhadap Pertumbuhan dan Produksi Kentang (Solanum tuberosum L.). Buletin Anatomi dan Fisiologi. vol XV (2):1.

Poerwowidodo. 1992. Telaah Kesuburan Tanah. Bandung: Penerbit Angkasa.

Sajimin YC, Rahardjo dan Purwantari ND. 1991. Potensi Kotoran Kelinci Sebagai 
Pupuk Organik dan Pemanfaatannya Pada Tanaman Pakan Dan Sayuran. Bogor: Prosiding Lokakarya Nasional Potensi dan Peluang Pengembangan Usaha Agribisnis Kelinci. hal 156-161.
Salisbury BF dan Ross CCW. 1995. Fisiologi Tumbuhan. Jilid 3. Bandung: Institut Teknologi Bandung.

Tim Redaksi. 2006. Kelinci, Ternak yang Berfungsi Ganda. Warta Penelitian dan Pengembangan Pertanian. vol 31 (6):1. 